\title{
A Study of Environmental Factors that Affect Survival of Pumpkin Isolates of Verticillium dahliae
}

\author{
Sephra N. Rampersad \\ Department of Life Sciences, Faculty of Science and Agriculture, The \\ University of the West Indies, St. Augustine, The Republic of Trinidad and \\ Tobago, West Indies
}

Additional index words. disease control, growth requirements, microsclerotia production, Verticillium dahliae

\begin{abstract}
V$. dahliae is a destructive soilborne pathogen to many economically important crops worldwide. Knowledge of environmental influences, including temperature, source, and availability of nutrients and $\mathrm{pH}$, on disease development is central to devising control strategies. The effects of root decoction media, $\mathrm{pH}$, and temperature on radial growth and microsclerotia production in 32 Verticillium dahliae (Kleb.) isolates from Trinidad were investigated. There were significant differences $(P \leq 0.05)$ in colony diameters and growth rates for isolates grown on different media. The highest growth occurred on 5\% nutsedge root extract agar (NREA) and the least amount of growth was obtained on 1\% pumpkin root extract agar (PREA). Production of microsclerotia was significantly higher on 5\% PREA, 5\% NREA, and potato dextrose agar (PDA). Growth tests on PDA formulated to different $\mathrm{pH}$ levels revealed that the most growth occurred at pH 5.2, but this was not significantly different from colony diameters obtained at pH 4.2, 6.2, and 7.2. pH, however, had a pronounced effect on production of microsclerotia. The optimum temperature for radial growth and formation of microsclerotia in $\mathrm{V}$. dahliae in vitro was found to be $25 \pm 1^{\circ} \mathrm{C}$. The effects of isolates and temperature on incidence and symptom severity in susceptible pumpkin plants were also tested under controlled conditions. There was no significant difference in symptom severity when inoculated plants were grown at $25 \pm 1{ }^{\circ} \mathrm{C}$ and at $30 \pm 1{ }^{\circ} \mathrm{C}$. The pathogen was recovered from infected plants grown at $35 \pm 1{ }^{\circ} \mathrm{C}$, although growth is completely inhibited at this temperature in vitro. There was no significant difference among isolates in their pathogenic response at the four different temperatures tested.
\end{abstract}

Verticillium dahliae (Kleb.) is a destructive soilborne pathogen that infects many economically important agricultural crops worldwide. Wilt caused by $V$. dahliae is difficult to control because the fungus can survive in the soil as microsclerotia even in the absence of a suitable host (Bruehl, 1987; Griffiths, 1970; Wilhelm, 1955).

Microsclerotia are composed of compact, thick-walled, melanized cells that arise by budding from septate, swollen hyphae (Griffiths, 1970) and function to protect the pathogen against degradative enzymes and ultraviolet radiation and may act as food reservoirs (Isaac and McGarvie, 1966; Schnathorst, 1965, 1981). Environmental factors can stimulate or retard the production of microsclerotia (Chet and Hennis, 1975; Iannou et al., 1977). A reduction in melanin biogenesis and rate of deposition in microsclerotia would result in decreased survival of the pathogen (Tjamos and Fravel, 1995).

Received for publication 26 Apr. 2010. Accepted for publication 29 June 2010.

This work was supported by a grant from the University of the West Indies Campus Research and Publications Fund (Grant No. CRP.3.Feb07.7). I thank Ms. L. Teelucksingh and Ms. M. Goddard for technical assistance.

e-mail Sephra.Rampersad@sta.uwi.edu.
Recently, severe $V$. dahliae infection was reported in commercial pumpkin (Cucurbita реро L.) fields in Trinidad (Rampersad, 2008). The use of infected seed material in year-round plantings has ensured persistent and pervasive infection in these fields (Rampersad, 2010). Symptoms include foliar chlorosis, necrosis, and premature death of vines resulting in the production of immature fruit. Yield loss is estimated between $40 \%$ and $80 \%$ and has severely affected local and export market supply. Little information, if any, on the pumpkin pathosystem exists and methods of disease control remain largely uninformed.

Microclimate factors, including temperature, source, and availability of nutrients and soil $\mathrm{pH}$ can influence growth and susceptibility of the host, growth of the pathogen, and the host-pathogen interaction as it relates to disease development (Agrios, 1997; Bruehl, 1987; Garrett, 1970; Yamanaka, 2003). In some hosts, (e.g., tobacco, chrysanthemum, and Arabidopsis), development of verticillium wilt is related to the initiation of flowering, which in turn is linked to environmental conditions (Robb, 2007). Environmental factors can also act as triggers of specific developmental pathways of the pathogen, which may affect its ability to adapt to and exploit a range of ecological niches in either sapro- phytic or parasitic states (Deacon, 2006; Robb, 2007). Knowledge of environmental influences on disease development is central to devising control strategies.

The objective of this study was to determine isolate, media, $\mathrm{pH}$, and temperature effects on radial growth and production of microsclerotia in $V$. dahliae isolates in vitro. Isolate and temperature effects on infection of pumpkin plants under controlled conditions were also investigated with the aim of developing a predictive model for use in field studies.

\section{Materials and Methods}

Isolate collection and maintenance

Thirty-two single-spore-derived isolates of $V$. dahliae, originally isolated from fieldinfected pumpkin plants collected from at least 15 commercial fields in Trinidad, were maintained on potato dextrose agar (PDA; Oxoid Ltd., U.K.), slants at $4{ }^{\circ} \mathrm{C}$ and used in vitro experiments. Conidial suspensions in glycerol were kept at $-70{ }^{\circ} \mathrm{C}$ for long-term storage of isolates. All experimental plates were seeded with a 4- $\mathrm{mm}^{3}$ agar block containing hyphae from the advancing edge of a 7-d-old culture of each isolate. The cultures were incubated for $6 \mathrm{~d}$ in the dark at $25 \pm 1{ }^{\circ} \mathrm{C}$ unless otherwise stated. Tests were carried out in duplicate and the experiment was conducted twice for each isolate/treatment combination.

The effect of media type on radial growth and formation of microsclerotia in $V$. dahliae isolates

The effects of five different media types on radial growth and microsclerotia production in $V$. dahliae isolates from Trinidad were investigated. Radial growth on pumpkin root extract agar (PREA) and nutsedge root extract agar (NREA) was compared with that on PDA (Oxoid Ltd.), CZ-Dox agar (CZA) (Kim et al., 2005), and ethanol-amended agar (EA) (Nadakavukaren and Horner, 1959). Root extract agar at $1 \%$ and $5 \%$ concentrations were prepared from pumpkin and nutsedge plants (Cyperus esculentus L.), which were grown in sterile Promix ${ }^{\mathrm{TM}}$ for 1 month in the greenhouse. Root tissue was collected from the plants and washed in distilled water to remove potting medium. Then, $10 \mathrm{~g} \cdot \mathrm{L}^{-1}(1 \%)$ and $50 \mathrm{~g} \cdot \mathrm{L}^{-1}(5 \%)$ of root tissue was macerated in $500 \mathrm{~mL}$ distilled water and filtered through two layers of mira cloth. The final volume of the filtrate was brought to $1 \mathrm{~L} ; 20 \mathrm{~g}$ agar (BactoAgar; Difco Laboratories) was added and then autoclaved. All media were supplemented with $50 \mathrm{mg} \cdot \mathrm{L}^{-1}$ streptomycin, tetracycline, and chloramphenicol (Sigma Ltd., St. Louis, MO). Under a stereomicroscope, the colony diameter (orthogonal measurements) and the proportion of colony-forming microsclerotia were measured daily. The proportion of the colony-forming microsclerotia was determined using an index (Fig. 1) in which: $0=0 \%$ colony-formed microsclerotia; $1=1 \%$ to $24 \%$ colony-formed microsclerotia; $2=25 \%$ to $49 \%$ colony-formed 
microsclerotia; $3=50 \%$ to $74 \%$ colonyformed microsclerotia; and $4=75 \%$ to $100 \%$ colony-formed microsclerotia.

Rate of growth was calculated according to Eq. 1 (Trinci and Gull, 1970):

$$
\mathrm{K}_{r}=\left(\mathrm{d}_{1}-\mathrm{d}_{0}\right) /\left(\mathrm{t}_{1}-\mathrm{t}_{0}\right)
$$

where $d_{1}$ and $d_{0}$ are radial colony diameter at initial $\left(t_{0}\right)$ and elapsed times $\left(t_{1}\right)$ as determined from linear regression of a plot of colony diameter (mm) versus time (days). Growth rate was expressed as $\mathrm{mm} \cdot \mathrm{d}^{-1}$.

\section{The effect of $\mathrm{pH}$ on radial growth and production of microsclerotia in \\ $V$. dahliae isolates}

The acidity requirements for optimal growth of $32 \mathrm{~V}$. dahliae isolates were evaluated on PDA media adjusted to four $\mathrm{pH}$ levels: $\mathrm{pH} 4.2,5.2,6.2$, and 7.2 using $10 \mathrm{M}$ $\mathrm{NaOH}$ or $10 \mathrm{M}$ HCL as needed. Allowances were made for a 0.2-point drop in $\mathrm{pH}$ after autoclaving. Media of $\mathrm{pH} 4.2$ was adjusted after autoclaving; otherwise, the agar would not set properly. $\mathrm{pH}$ was measured using a glass body Calomel $\mathrm{pH}$ electrode (Beckman Instruments, Inc.). Colony and microsclerotia measurements were taken as previously described.

\section{The effect of temperature on radial growth and production of microsclerotia in $V$. dahliae isolates}

The temperature requirements for optimal growth of $32 \mathrm{~V}$. dahliae isolates from pumpkin were evaluated at five temperatures: $15 \pm$ $1,20 \pm 1,25 \pm 1,30 \pm 1$, and $35 \pm 1{ }^{\circ} \mathrm{C}$. Seeded plates were incubated and measurements were taken as previously described.

\section{Symptom severity at different temperatures}

Based on the results of the effects of temperature on survival of $V$. dahliae isolates, the ability of five arbitrarily selected isolates to induce wilt symptoms in pumpkin (var. 'Jamaican squash') was tested at four different temperatures: $20 \pm 1,25 \pm 1,30 \pm 1$, and $35 \pm 1^{\circ} \mathrm{C}$.

Preparation of inoculum. Conidia were harvested by flooding the surface of a 7-d-old culture with $10 \mathrm{~mL}$ sterile distilled water. The surface was then scraped with a sterile scalpel blade and the resulting suspension was filtered through two layers of sterile mira cloth. The number of conidia in the suspension was determined using a hemocytometer under dark field microscopy $(\times 100)$ and adjusted to 2.0 to $2.6 \times 10^{6}$ conidia $/ \mathrm{mL}$.

Preparation of test plants. Seeds were sown in sterile potting mix in seedling trays. Seedlings at the two- to three-true-leaf stage were inoculated using the root-dip method (Koike et al., 1994), 10 plants per isolate. Seedlings were removed from trays, washed free of soil, and $2 \mathrm{~cm}$ of tap root was trimmed. The seedlings were inoculated by dipping their roots in the conidial suspension for $20 \mathrm{~min}$. The inoculated plants were planted in black planting bags $(25 \mathrm{~cm} \times 13 \mathrm{~cm})$ containing sterile potting soil. Negative con- trols were seedlings whose roots were cut and dipped in sterile distilled water. Plants were kept in temperature-controlled growth rooms (12:12 alternating light and dark cycles) at each specified temperature and monitored for the onset of symptoms. The test was ended at the flowering stage of the plants (35 d postinoculation). Symptom severity was scored according to a rating scale in which $0=0 \%$ leaves chlorotic and/or necrotic; $1=1 \%$ to $9 \%$ leaves chlorotic and/or necrotic; $2=10 \%$ to $24 \%$ leaves chlorotic and/or necrotic; $3=$ $25 \%$ to $49 \%$ leaves chlorotic and/or necrotic; $4=50 \%$ to $74 \%$ leaves; $5=75 \%$ to $99 \%$ chlorotic and/or necrotic leaves; and $6=$ dead plant.

Isolation of the pathogen. The main root and a $10-\mathrm{cm}$ section of the stem (at the soil line) of each plant were cut and prepared for re-isolation of the pathogen. Each tissue sample was rinsed with water under high pressure for $10 \mathrm{~s}$; soaked for $2 \mathrm{~min}$, with agitation, in $0.6 \%$ sodium hypochlorite solution containing a few drops of Tween-20; followed by three rinses in sterile distilled water. The sections were then soaked, with agitation, in $70 \%$ ethanol for $2 \mathrm{~min}$ followed by three rinses in sterile distilled water. Stem tissue was divided into three segments: up to $1 \mathrm{~cm}=$ stem base near soil line; up to $3 \mathrm{~cm}=$ middle portion of stem section; and up to $5 \mathrm{~cm}=$ top portion of stem section. Surface sterilized tissue sections were aseptically transferred to ethanol-amended agar. Hyphae from the advancing edge of colonies were subcultured onto PDA media. Incubations were carried out at $25 \pm 1{ }^{\circ} \mathrm{C}$ in the dark for a 2-week period. The identity of the pathogen was determined by morphological characterization of colonies, conidia, and the presence and distribution of microsclerotia (Griffiths, 1970; Hawksworth and Talboys, 1970). The final symptom severity score, degree of stem colonization, fresh weight, and dry weight to constant mass were determined for inocu- lated and control plants at each temperature. For further statistical analyses, the mean percentage of symptomatic leaves on inoculated plants and the time to maximum symptom severity were also recorded. The test was conducted twice.

\section{Statistical analyses}

Analyses of variance were conducted to determine the significance of differences in colony diameters obtained for three treatments: five different media, PDA adjusted to four different acidic $\mathrm{pH}$ levels, and five different temperatures. The presence of isolate/ media, isolate $/ \mathrm{pH}$, and isolate/temperature interactions was first verified by constructing separate interaction plots. A General Linear Model was then used to determine the significance of media, $\mathrm{pH}$, temperature, and isolates as main effects. Comparison of means was carried out using Fisher's least significant difference test at $P \leq 0.05$. Percentages were arcsine-transformed before analysis. Data taken as ordinal values were analyzed using the Kruskal-Wallis test. Replications did not serve as sources of variation and the mean values and SE of the mean for all experiments were computed. All statistical analyses were computed using MINITAB 15.0 software package for Windows (MINITAB Inc.).

\section{Results}

The effect of media on radial growth and production of microsclerotia. Significant differences $(P \leq 0.05)$ in colony diameters and growth rates for isolates grown on five different media types were observed (Table 1). The most growth was obtained for isolates grown on 5\% NREA (Fig. 2A). Colony diameters for isolates grown on PDA and $5 \%$ PREA were not significantly different $(P \leq 0.05)$. Similar results were found for isolates grown on 1\% NREA and CZA. The least growth occurred for isolates grown on

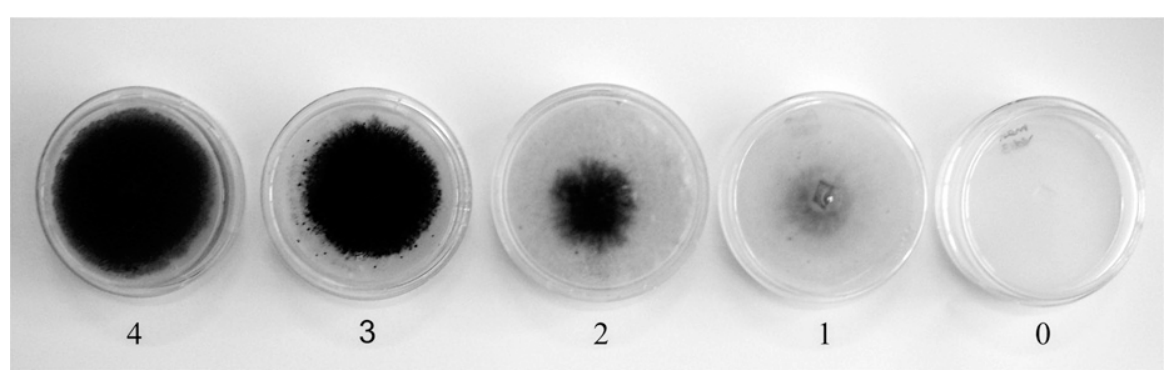

Fig. 1. Index to describe the production of microsclerotia in Verticillium dahliae isolates. Microsclerotia score was determined according to an index in which $0=0 \%$ colony-formed microsclerotia; $1=1 \%$ to $24 \%$ colony-formed microsclerotia; $2=25 \%$ to $49 \%$ colony-formed microsclerotia; $3=50 \%$ to $74 \%$ colony-formed microsclerotia; and $4=75 \%$ to $100 \%$ colony-formed microsclerotia.

Table 1. Analysis of variance of the effect of media on radial colony growth of Verticillium dahliae isolates from pumpkin.

\begin{tabular}{lrrccrr}
\hline Source & df & Seq SS & Adjusted SS & Adjusted MS & F & $P$ \\
\hline Isolate & 31 & 392.9 & 392.9 & 12.7 & 1.07 & 0.377 \\
Media & 6 & 3315.1 & 3315.1 & 552.5 & 46.63 & $<0.001$ \\
Total & 223 & 5912.1 & & & & \\
\hline
\end{tabular}

Seq $\mathrm{SS}=$ sequential sum of squares; $\mathrm{MS}=$ mean squares. 

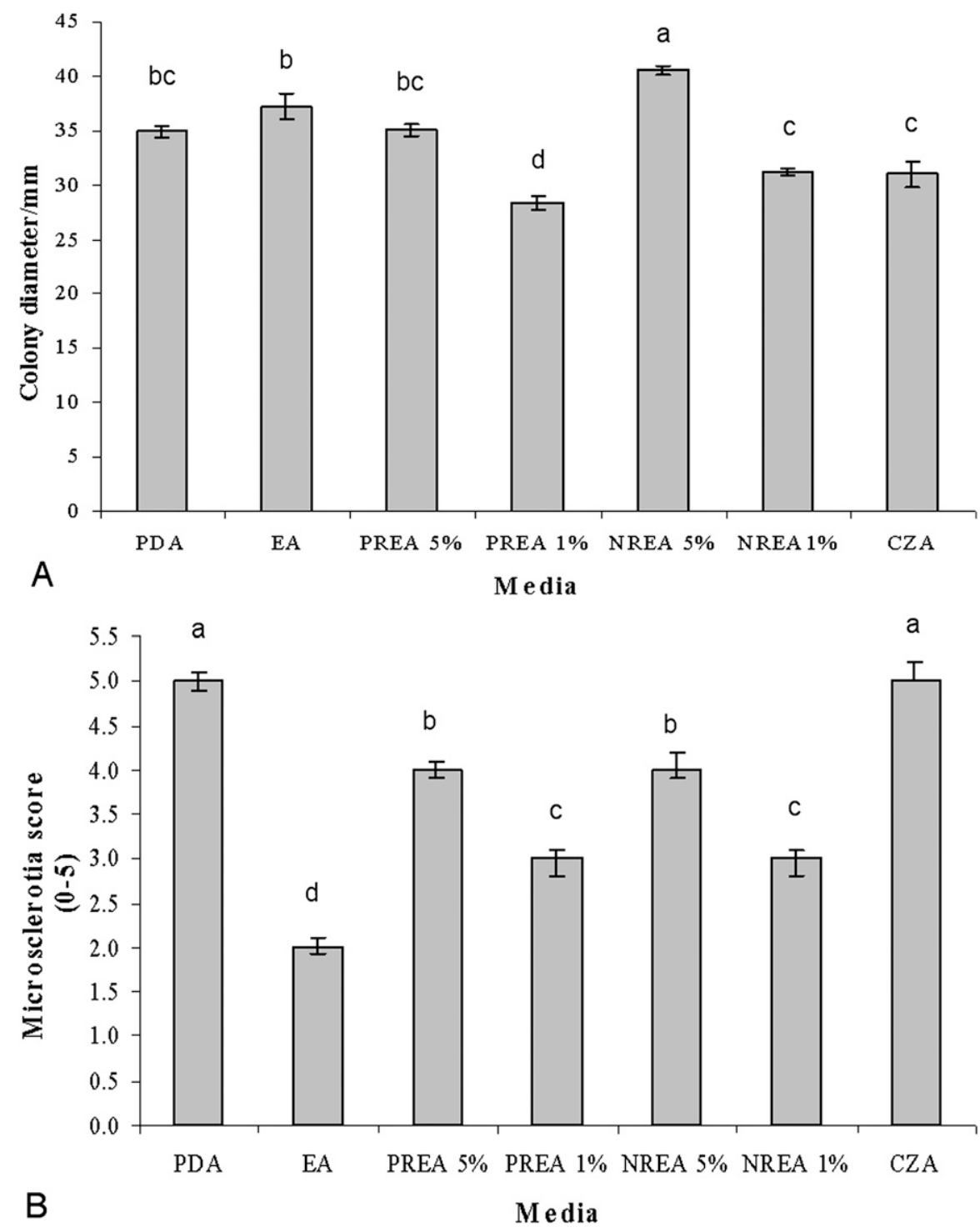

Fig. 2. (A) The effects of media on radial growth of Verticillium dahliae isolates. PDA = potato dextrose agar; EA = ethanol-amended agar; PREA = pumpkin root extract agar; NREA = nutsedge root extract agar; $\mathrm{CZA}=\mathrm{CZ}$-Dox agar. Error bars as SE of the mean. Numbers above vertical bars are not significantly different according to a least significant difference test at $P \leq 0.05$. (B) The effects of media on microsclerotia production in Verticillium dahliae isolates. Microsclerotia score was determined according to an index in which $0=0 \%$ colony-formed microsclerotia; $1=1 \%$ to $24 \%$ colony-formed microsclerotia; $2=25 \%$ to $49 \%$ colony-formed microsclerotia; $3=50 \%$ to $74 \%$ colonyformed microsclerotia; and $4=75 \%$ to $100 \%$ colony-formed microsclerotia. PDA $=$ potato dextrose agar; EA = ethanol-amended agar; PREA = pumpkin root extract agar; NREA = nutsedge root extract agar; $\mathrm{CZA}=\mathrm{CZ}$-Dox agar. Error bars as SE of the mean. Numbers above vertical bars are not significantly different according to a least significant difference test at $P \leq 0.05$.

$1 \%$ PREA. The most suitable media in order of preference for optimum growth rate (GR) was found to be: 5\% NREA (GR $=8.2$ $\left.\mathrm{mm} \cdot \mathrm{d}^{-1}\right)>\mathrm{EA}\left(\mathrm{GR}=7.4 \mathrm{~mm} \cdot \mathrm{d}^{-1}\right)>5 \%$ PREA $\left(\mathrm{GR}=7.0 \mathrm{~mm} \cdot \mathrm{d}^{-1}\right) \geq \operatorname{PDA}(\mathrm{GR}=6.9$ $\left.\mathrm{mm} \cdot \mathrm{d}^{-1}\right)>1 \%$ NREA $\left(\mathrm{GR}=6.2 \mathrm{~mm} \cdot \mathrm{d}^{-1}\right) \geq$ $\mathrm{CZA}\left(\mathrm{GR}=6.2 \mathrm{~mm} \cdot \mathrm{d}^{-1}\right)>1 \%$ PREA $(\mathrm{GR}=$ $\left.5.7 \mathrm{~mm} \cdot \mathrm{d}^{-1}\right)$ (Fig. 2A).

Media had a considerable effect on microsclerotia production among isolates tested (Fig. 2B). Microsclerotia production was not significantly different $(P \leq 0.05)$ for isolates grown on PDA and CZA, on $5 \%$ PREA and $5 \%$ NREA, and on $1 \%$ PREA and $1 \%$ NREA. A significant reduction in the amount of microsclerotia $(P \leq 0.05)$ on $1 \%$

PREA, 1\% NREA, and EA was observed. The highest production occurred on PDA and CZ media followed by $5 \%$ PREA, $5 \%$ NREA, EA, $1 \%$ PREA, and $1 \%$ NREA.

The effect of $\mathrm{pH}$ on radial growth and production of microsclerotia. $\mathrm{pH}$ affected radial growth of all $V$. dahliae isolates tested (Fig. 3A) and mean growth rates for isolates grown at $\mathrm{pH} 4.2,5.2,6.2$, and 7.2 were significantly different $(P \leq 0.01)$. Growth rates at $\mathrm{pH} 5.2\left(8.5 \mathrm{~mm} \cdot \mathrm{d}^{-1}\right)$ were significantly higher $(P \leq 0.01)$ than at any other acidity level tested. Mean growth rates at $\mathrm{pH}$ $4.2,6.2$, and 7.2 were not significantly different $(P \leq 0.05)$ (Table 2$)$. Acidity of the growth medium also affected microscler-
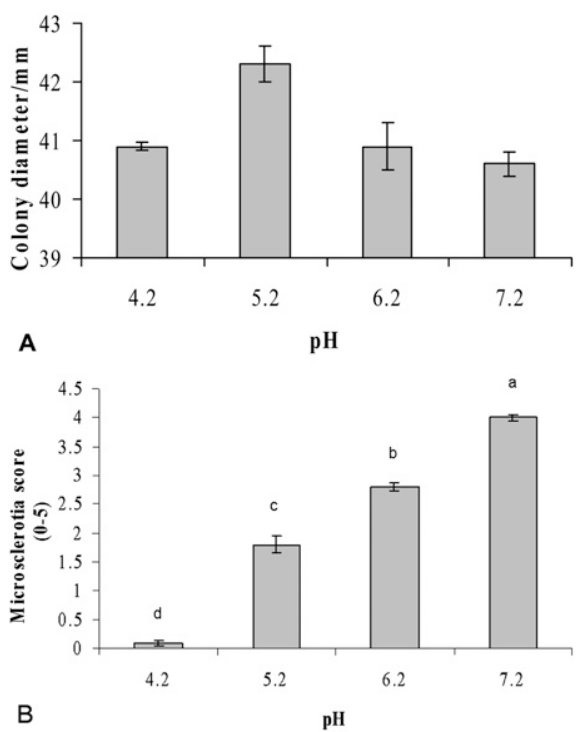

Fig. 3. (A) Effect of $\mathrm{pH}$ on radial growth of Verticillium dahliae isolates. Error bars as $\mathrm{SE}$ of the mean. Numbers above vertical bars are not significantly different according to a least significant difference test at $P \leq 0.05$. (B) Effect of $\mathrm{pH}$ on microsclerotia production in Verticillium dahliae isolates. MS score $=$ microsclerotia score determined according to an index in which $0=0 \%$ colony-formed microsclerotia; $1=1 \%$ to $24 \%$ colony-formed microsclerotia; $2=25 \%$ to $49 \%$ colony-formed microsclerotia; $3=50 \%$ to $74 \%$ colony-formed microsclerotia; and $4=$ $75 \%$ to $100 \%$ colony-formed microsclerotia. Error bars as SE of the mean. Numbers above vertical bars are not significantly different according to a least significant difference test at $P \leq 0.05$.

Table 2. Analysis of variance of the effect of $\mathrm{pH}$ on radial colony growth for isolates of Verticillium dahliae from pumpkin.

\begin{tabular}{lrrrcc}
\hline Source & df & \multicolumn{1}{c}{ SS } & MS & F & $P$ \\
\hline Isolate & 31 & 403.5 & 13.0 & 2.1 & 0.004 \\
pH & 3 & 56.8 & 18.9 & 3.02 & 0.034 \\
Total & 127 & 1043.0 & & & \\
\hline
\end{tabular}

$\mathrm{SS}=$ sum of squares; MS = mean squares.

otia formation and there was a significant difference among microsclerotia scores (MS) $(P \leq 0.05)$ (Fig. 3B). An extension of the incubation time to $14 \mathrm{~d}$ did not improve growth or formation of microsclerotia at any $\mathrm{pH}$ level.

The effect of temperature on radial growth and production of microsclerotia. Temperature had a significant effect on growth and formation of microsclerotia in $V$. dahliae isolates $(P \leq 0.05)$ (Tables 3 and $4)$. The temperature for optimal growth and formation of microsclerotia in $V$. dahliae isolates was $25 \pm 1{ }^{\circ} \mathrm{C}$ followed by $30 \pm 1$ ${ }^{\circ} \mathrm{C}$. No growth was observed at temperatures $35 \pm 1$ and $15 \pm 1{ }^{\circ} \mathrm{C}$. Twenty-five percent of the isolates grew at $20 \pm 1{ }^{\circ} \mathrm{C}$, but the radial diameter was $4.0 \mathrm{~mm}$ or less and colonies were without microsclerotia. Colony diameters at $30 \pm 1{ }^{\circ} \mathrm{C}\left(\right.$ mean $\left.\mathrm{GR}=2.3 \mathrm{~mm} \cdot \mathrm{d}^{-1}\right)$ were approximately one-third those obtained for all isolates incubated at $25 \pm 1{ }^{\circ} \mathrm{C}$. Sixty- 
Table 3. Effect of temperature on radial growth and formation of microsclerotia of Verticillium dahliae isolates from Trinidad.

\begin{tabular}{|c|c|c|c|c|c|c|c|c|c|c|}
\hline \multirow[b]{3}{*}{ Isolate } & \multicolumn{10}{|c|}{ Temperature range $\left({ }^{\circ} \mathrm{C}\right)$} \\
\hline & \multicolumn{2}{|c|}{$15 \pm 1$} & \multicolumn{2}{|c|}{$20 \pm 1$} & \multicolumn{2}{|c|}{$25 \pm 1$} & \multicolumn{2}{|c|}{$30 \pm 1$} & \multicolumn{2}{|c|}{$35 \pm 1$} \\
\hline & $\begin{array}{l}\text { Colony } \\
\text { diameter }\end{array}$ & $\begin{array}{c}\text { MS } \\
\text { score }^{y}\end{array}$ & $\begin{array}{c}\text { Colony } \\
\text { diameter }\end{array}$ & $\begin{array}{c}\text { MS } \\
\text { score }\end{array}$ & $\begin{array}{c}\text { Colony } \\
\text { diameter }\end{array}$ & $\begin{array}{c}\text { MS } \\
\text { score }\end{array}$ & $\begin{array}{l}\text { Colony } \\
\text { diameter }\end{array}$ & $\begin{array}{c}\text { MS } \\
\text { score }\end{array}$ & $\begin{array}{l}\text { Colony } \\
\text { diameter }\end{array}$ & $\begin{array}{c}\text { MS } \\
\text { score }\end{array}$ \\
\hline$\overline{\text { Mean } \pm \mathrm{SE}^{\mathrm{x}}}$ & $0.0 \pm 0.0$ & $0.0 \pm 0.0$ & $0.77 \pm 0.26$ & $0.0 \pm 0.0$ & $34.86 \pm 0.57$ & $5.0 \pm 0.0$ & $11.26 \pm 1.06$ & $0.62 \pm 0.09$ & $0.0 \pm 0.0$ & $0.0 \pm 0.0$ \\
\hline Minimum & 0.0 & 0.0 & 0.0 & 0.0 & 28.7 & 0.0 & 0.0 & 0.0 & 0.0 & 0.0 \\
\hline Maximum & 0.0 & 0.0 & 4.3 & 0.0 & 40.2 & 5.0 & 18.2 & 1.0 & 0.0 & 0.0 \\
\hline
\end{tabular}

${ }^{\mathrm{z}}$ Colony diameter (in millimeters) was not significantly different between experiments; hence, the mean value of both experiments is presented.

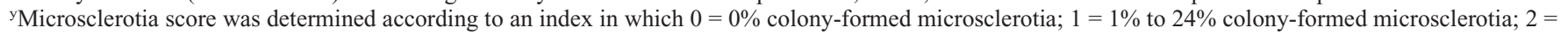
$25 \%$ to $49 \%$ colony-formed microsclerotia; $3=50 \%$ to $74 \%$ colony-formed microsclerotia; and $4=75 \%$ to $100 \%$ colony-formed microsclerotia.

${ }^{\mathrm{x}}$ Mean values with $\mathrm{SE}$ of the mean for 32 isolates.

Table 4. Analysis of variance of the effect of temperature on radial colony growth for isolates of Verticillium dahliae from Trinidad.

\begin{tabular}{lrrrrr}
\hline Source & df & \multicolumn{1}{c}{ SS } & \multicolumn{1}{c}{ MS } & \multicolumn{1}{c}{ F } & \multicolumn{1}{c}{$P$} \\
\hline Isolate & 31 & 356.1 & 11.8 & 1.3 & 0.189 \\
Temperature & 4 & 28784.2 & 7196.1 & 768.6 & $<0.001$ \\
Total & 159 & 30310.4 & & & \\
\hline
\end{tabular}

$\mathrm{SS}=$ sum of squares; MS = mean squares.

three percent of the isolates at $30 \pm 1{ }^{\circ} \mathrm{C}$ had an MS score of 1 .

An extended incubation time of $14 \mathrm{~d}$ at $20 \pm 1{ }^{\circ} \mathrm{C}$ resulted in a significant increase $(P \leq 0.05)$ in colony diameter for $25 \%$ of the isolates, but the MS score remained zero. At $30 \pm 1{ }^{\circ} \mathrm{C}$, the mean colony diameter increased by $57 \%$. The extended time at $30 \pm$ $1{ }^{\circ} \mathrm{C}$ also resulted in larger colony diameters and an increase in MS score by a factor of one for $75 \%$ of the isolates. Thirty-eight percent of the isolates had up to $50 \%$ of the colonyforming microsclerotia.

Isolate and interaction effects. There was no isolate/media or isolate $/ \mathrm{pH}$ interaction. Media type and $\mathrm{pH}$ level were the only significant contributors to the observed differences in colony diameter of the isolates. There was no isolate/temperature interaction. No significant $(P \leq 0.05)$ variation in colony diameter among isolates grown at different temperatures was found. Temperature was the only significant contributor to the observed differences in colony diameter and microsclerotia production in the isolates.

Symptom severity at different temperatures. V. dahliae was consistently recovered from all inoculated plants but was absent from all negative controls (Table 5A-D). Inoculated plants had significantly $(P \leq$ $0.05)$ more symptomatic leaves than noninoculated control plants except for those grown at $20 \pm 1{ }^{\circ} \mathrm{C}$. The pathogen was recovered from the roots of all inoculated plants irrespective of temperature at which plants were maintained. Soil temperature was the same as the ambient temperature of the growth room, except at $35 \pm 1{ }^{\circ} \mathrm{C}$ in which the soil temperature was $33{ }^{\circ} \mathrm{C}$. Root and shoot fresh/dry weights in infected plants were significantly lower $(P \leq 0.05)$ compared with non-inoculated controls. Symptom severity was not significantly different $(P \leq 0.05)$ at $25 \pm 1$ and $30 \pm 1{ }^{\circ} \mathrm{C}$. In addition, the pathogen was recovered from the uppermost portion (up to $5 \mathrm{~cm}$ ) of the stem section of inoculated plants grown at both temperatures.
However, at $20 \pm 1{ }^{\circ} \mathrm{C}$, symptom severity scores were significantly lower $(P \leq 0.05)$ than were obtained at higher temperatures. Colonization of stem segments was also limited to the first one-third (up to $1 \mathrm{~cm}$ ) of the $10-\mathrm{cm}$ stem section used in the test. At $35 \pm 1{ }^{\circ} \mathrm{C}$, plants had lower root and shoot weights and higher symptoms severity scores. Inoculated plants at $35 \pm 1{ }^{\circ} \mathrm{C}$ also died 3 to 4 weeks post-inoculation. This is in contrast to infected plants grown at lower temperatures in which maximum symptoms developed 5 to 6 weeks post-inoculation and plants did not die. Table 6A-B summarizes the analyses of variance for the effect of temperature on symptom severity and on time to maximum symptom severity in inoculated plants.

\section{Discussion}

Understanding the relationships between environmental factors and survival of a pathogen is important to clarifying specific ecophysiological bases for the establishment and persistence of infection. The effects of media, $\mathrm{pH}$, and temperature effects on radial growth and production of microsclerotia in $V$. dahliae isolates in vitro were studied. Isolate and temperature effects on infection of pumpkin plants under controlled conditions were also investigated.

Induction of microsclerotia germination and hyphal growth occur along a chemotaxic gradient in the soil matrix through a complex signal transduction mechanism (Broeckling et al., 2008), one of the most important triggers being plant root exudates from damaged or intact roots (Bruehl, 1987; Garrett, 1970; Mol, 1995; Schroth and Hildebrand, 1964). Root exudates can contribute to the nutritional status of the pathogen and inhibit saprophytic or parasitic activities (Schroth and Hildebrand, 1964). Fayazalla et al. (2008) evaluated growth of $V$. dahliae isolates from tomato on four different vegetable decoction media and found that growth was significantly greater on PDA and potato carrot agar. Conversely, Smolińska and Kowalska (2008) reported that growth of $V$. dahliae isolates from pepper was considerably reduced on PDA supplemented with $5 \%$ rapeseed meal extract or $5 \%$ tomato extract. Microsclerotia production was also inhibited. Sanogo (2007) concluded that growth of $V$. dahliae isolates from pepper on V8 agar, PDA, water agar, and CZA was not significantly different. In this study, radial growth was generally greater on root extract agar media than on artificial media, and there was significantly more growth on nutsedge extract agar than on pumpkin root extract agar. Nutsedge has been reported to be a weed host of $V$. dahliae in cotton agroecosystems (Johnson et al., 1980). Nutsedge is one of the most common perennial weeds found in pumpkin fields and other landscapes throughout Trinidad. Further investigation should be carried out to identify whether nutsedge can contribute to a build-up of inoculum in the soil in pumpkin production areas in Trinidad.

Few studies describe the differential effects of $\mathrm{pH}$ on radial growth and microsclerotia formation of $V$. dahliae. Dutta (1981) reported that $V$. dahliae grew in a wide $\mathrm{pH}$ range of acid and alkaline media $(\mathrm{pH} 3.5$ to 10.5); however, the most growth was observed at $\mathrm{pH}$ 5.5. Kabir et al. (2004) reported that media with a $\mathrm{pH}$ of 5.03 supported growth of $V$. dahliae isolates compared with media with extremes of $\mathrm{pH}$ (3.16 and 8.41). Microsclerotia production was also highest at $\mathrm{pH}$ 5.03. Fayazalla et al. (2008) indicated that $\mathrm{pH} 8$ promoted the most growth of $V$. dahliae isolates. The findings of this work suggest that the $\mathrm{pH}$ value of the microenvironment was a determinant for the developmental stage of $V$. dahliae isolates in vitro. The greatest growth for $V$. dahliae

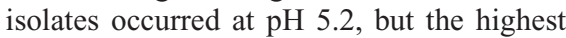
production of microsclerotia was at $\mathrm{pH} 7.2$. Among isolates, there were significant differences in colony diameter, which may be explained by an adaptation of isolates to survive in microsites, which exist in individual fields, and/or changes in soil $\mathrm{pH}$ resulting from rainfall (Bruehl, 1987). In Trinidad, the soil $\mathrm{pH}$ in pumpkin fields ranges from 4.5 to 7.5 (data not shown). V. dahliae is pervasive in pumpkin fields regardless of soil $\mathrm{pH}$. This adaptability may be reflected by the in vitro results of this study.

Optimal growth of $V$. dahliae isolates in vitro has been reported for temperatures between 22 and $25{ }^{\circ} \mathrm{C}$ (Pegg and Brady, 2002). Fayazalla et al. (2008) and Subbarao et al. (1995) both reported that growth was optimal at $25{ }^{\circ} \mathrm{C}$ followed by $20{ }^{\circ} \mathrm{C}$. The optimum temperature for mycelial growth and production of microsclerotia of pumpkin isolates was $25 \pm 1{ }^{\circ} \mathrm{C}$ followed by $30 \pm 1{ }^{\circ} \mathrm{C}$. Growth and production of microsclerotia were supported at $30 \pm 1{ }^{\circ} \mathrm{C}$ albeit at a slower 
Table 5A. Data for growth of inoculated plants at $20^{\circ} \mathrm{C}$.

\begin{tabular}{|c|c|c|c|c|c|c|c|c|}
\hline \multirow[b]{2}{*}{ Isolate $^{z}$} & \multirow{2}{*}{$\begin{array}{c}\text { Symptom } \\
\text { severity score }^{y}\end{array}$} & \multicolumn{3}{|c|}{ Colonization of stem segments (\%) } & \multirow{2}{*}{$\begin{array}{c}\text { Root } \\
\text { fresh wt } / g^{w}\end{array}$} & \multirow{2}{*}{$\begin{array}{l}\text { Root dry } \\
\text { wt } / g^{v}\end{array}$} & \multirow{2}{*}{$\begin{array}{c}\text { Shoot } \\
\text { fresh wt/gu }\end{array}$} & \multirow{2}{*}{$\begin{array}{c}\text { Shoot } \\
\text { dry wt } / g^{t}\end{array}$} \\
\hline & & $1 \mathrm{~cm}$ & $3 \mathrm{~cm}$ & $5 \mathrm{~cm}$ & & & & \\
\hline$\overline{V d 1}$ & $2.0 \mathrm{a}$ & $100.0 \mathrm{a}$ & $80.0 \mathrm{a}$ & 0.0 & $4.5 \mathrm{c}$ & $1.5 \mathrm{~b}$ & $19.9 \mathrm{c}$ & $0.53 \mathrm{~b}$ \\
\hline $\mathrm{Vd} 2$ & $1.0 \mathrm{~b}$ & $100.0 \mathrm{a}$ & $50.0 \mathrm{c}$ & 0.0 & $6.9 \mathrm{~b}$ & $2.5 \mathrm{ab}$ & $23.8 \mathrm{~b}$ & $0.68 \mathrm{a}$ \\
\hline $\mathrm{Vd} 5$ & $2.0 \mathrm{a}$ & $100.0 \mathrm{a}$ & $25.0 \mathrm{~d}$ & 0.0 & $4.9 \mathrm{c}$ & $2.2 \mathrm{ab}$ & $18.3 \mathrm{c}$ & $0.33 \mathrm{c}$ \\
\hline Vd6 & $1.0 \mathrm{~b}$ & $100.0 \mathrm{a}$ & $65.0 \mathrm{~b}$ & 0.0 & $7.4 \mathrm{a}$ & $2.6 \mathrm{a}$ & $24.7 \mathrm{~b}$ & $0.71 \mathrm{a}$ \\
\hline $\mathrm{Vd} 8$ & $1.0 \mathrm{~b}$ & $100.0 \mathrm{a}$ & $30.0 \mathrm{~d}$ & 0.0 & $6.8 \mathrm{~b}$ & $2.8 \mathrm{a}$ & $24.3 \mathrm{~b}$ & $0.7 \mathrm{a}$ \\
\hline Mean \pm SE & $1.4 \pm 0.24$ & $100.0 \pm 0.0$ & $50.0 \pm 10.3$ & $0.0 \pm 0.0$ & $6.1 \pm 0.58$ & $2.3 \pm 0.2$ & $22.2 \pm 1.3$ & $0.59 \pm 0.1$ \\
\hline Minimum & 1.0 & 100.0 & 25.0 & 0.0 & 4.5 & 1.5 & 18.3 & 0.33 \\
\hline Maximum & 2.0 & 100.0 & 80.0 & 0.0 & 7.4 & 2.8 & 24.7 & 0.71 \\
\hline $\begin{array}{l}\text { Mean } \pm \mathrm{SE} \\
\quad(\text { negative control) }\end{array}$ & $0.0 \pm 0.0^{\mathrm{s}}$ & $0.0 \pm 0.0^{\mathrm{s}}$ & $0.0 \pm 0.0^{\mathrm{s}}$ & $0.0 \pm 0.0^{\mathrm{s}}$ & $6.9 \pm 0.03 \mathrm{a}$ & $2.7 \pm 0.05 \mathrm{a}$ & $26.1 \pm 0.7 \mathrm{a}$ & $0.62 \pm 0.02 \mathrm{a}$ \\
\hline
\end{tabular}

Table 5B. Data for growth of inoculated plants at $25^{\circ} \mathrm{C}$.

\begin{tabular}{|c|c|c|c|c|c|c|c|c|}
\hline \multirow[b]{2}{*}{ Isolate $^{z}$} & \multirow{2}{*}{$\begin{array}{c}\text { Symptom } \\
\text { severity score }^{\mathrm{y}}\end{array}$} & \multicolumn{3}{|c|}{ Colonization of stem segments (\%) } & \multirow{2}{*}{$\begin{array}{c}\text { Root } \\
\text { fresh wt } / g^{w}\end{array}$} & \multirow{2}{*}{$\begin{array}{c}\text { Root } \\
\text { dry wt/gv }\end{array}$} & \multirow{2}{*}{$\begin{array}{c}\text { Shoot } \\
\text { fresh wt/gu }\end{array}$} & \multirow{2}{*}{$\begin{array}{c}\text { Shoot } \\
\text { dry wt } / g^{t}\end{array}$} \\
\hline & & $1 \mathrm{~cm}$ & $3 \mathrm{~cm}$ & $5 \mathrm{~cm}$ & & & & \\
\hline$\overline{\mathrm{Vd} 1}$ & $4.0 \mathrm{~b}$ & $100.0 \mathrm{a}$ & $100.0 \mathrm{a}$ & $100.0 \mathrm{a}$ & $2.2 \mathrm{~d}$ & $0.21 \mathrm{c}$ & $12.6 \mathrm{c}$ & $0.35 \mathrm{~b}$ \\
\hline $\mathrm{Vd} 2$ & $3.0 \mathrm{c}$ & $100.0 \mathrm{a}$ & $100.0 \mathrm{a}$ & $100.0 \mathrm{a}$ & $4.5 \mathrm{~b}$ & $0.33 \mathrm{~b}$ & $16.1 \mathrm{bc}$ & $0.21 \mathrm{~d}$ \\
\hline Vd5 & $5.0 \mathrm{a}$ & $100.0 \mathrm{a}$ & $100.0 \mathrm{a}$ & $100.0 \mathrm{a}$ & $4.2 \mathrm{~b}$ & $0.24 \mathrm{c}$ & $17.2 \mathrm{~b}$ & $0.20 \mathrm{~d}$ \\
\hline Vd6 & $4.0 \mathrm{~b}$ & $100.0 \mathrm{a}$ & $100.0 \mathrm{a}$ & $100.0 \mathrm{a}$ & $3.8 \mathrm{c}$ & $0.36 \mathrm{~b}$ & $18.6 \mathrm{~b}$ & $0.27 \mathrm{c}$ \\
\hline $\mathrm{Vd} 8$ & $4.0 \mathrm{~b}$ & $100.0 \mathrm{a}$ & $100.0 \mathrm{a}$ & $100.0 \mathrm{a}$ & $4.2 \mathrm{~b}$ & $0.21 \mathrm{c}$ & $16.9 \mathrm{bc}$ & $0.29 \mathrm{c}$ \\
\hline Mean $\pm \mathrm{SE}$ & $5.0 \pm 0.32$ & $100.0 \pm 0.0$ & $100.0 \pm 0.0$ & $100.0 \pm 0.0$ & $3.78 \pm 0.41$ & $0.27 \pm 0.03$ & $16.28 \pm 1.00$ & $0.26 \pm 0.03$ \\
\hline Minimum & 3.0 & 100.0 & 100.0 & 100.0 & 2.2 & 0.21 & 12.6 & 0.2 \\
\hline Maximum & 5.0 & 100.0 & 100.0 & 100.0 & 4.5 & 0.36 & 18.6 & 0.3 \\
\hline $\begin{array}{l}\text { Mean } \pm \mathrm{SE} \\
\quad(\text { negative control) }\end{array}$ & $0.0 \pm 0.0^{\mathrm{s}}$ & $0.0 \pm 0.0^{\mathrm{s}}$ & $0.0 \pm 0.0^{\mathrm{s}}$ & $0.0 \pm 0.0^{\mathrm{s}}$ & $7.1 \pm 0.01 \mathrm{a}$ & $2.9 \pm 0.03 \mathrm{a}$ & $25.8 \pm 0.2 \mathrm{a}$ & $0.80 \pm 0.08 \mathrm{a}$ \\
\hline
\end{tabular}

Table 5C. Data for growth of inoculated plants at $30^{\circ} \mathrm{C}$.

\begin{tabular}{|c|c|c|c|c|c|c|c|c|}
\hline \multirow[b]{2}{*}{ Isolate $^{z}$} & \multirow{2}{*}{$\begin{array}{c}\text { Symptom } \\
\text { severity score }^{\mathrm{y}}\end{array}$} & \multicolumn{3}{|c|}{ Colonization of stem segments $(\%)$} & \multirow{2}{*}{$\begin{array}{c}\text { Root } \\
\text { fresh wt } / g^{w}\end{array}$} & \multirow{2}{*}{$\begin{array}{c}\text { Root } \\
\text { dry wt } / g^{v}\end{array}$} & \multirow{2}{*}{$\begin{array}{c}\text { Shoot } \\
\text { fresh wt } / g^{u}\end{array}$} & \multirow{2}{*}{$\begin{array}{c}\text { Shoot } \\
\text { dry wt } / \mathrm{g}^{\mathrm{t}}\end{array}$} \\
\hline & & $1 \mathrm{~cm}$ & $3 \mathrm{~cm}$ & $5 \mathrm{~cm}$ & & & & \\
\hline$\overline{\mathrm{Vd} 1}$ & $2.0 \mathrm{c}$ & $100.0 \mathrm{a}$ & $100.0 \mathrm{a}$ & $100.0 \mathrm{a}$ & $4.0 \mathrm{~b}$ & $0.45 \mathrm{~b}$ & $16.4 \mathrm{~b}$ & $0.22 \mathrm{c}$ \\
\hline $\mathrm{Vd} 2$ & $4.0 \mathrm{~b}$ & $100.0 \mathrm{a}$ & $100.0 \mathrm{a}$ & $100.0 \mathrm{a}$ & $2.9 \mathrm{c}$ & $0.35 \mathrm{c}$ & $19.0 \mathrm{~b}$ & $0.29 \mathrm{~b}$ \\
\hline Vd5 & $5.0 \mathrm{a}$ & $100.0 \mathrm{a}$ & $100.0 \mathrm{a}$ & $100.0 \mathrm{a}$ & $4.7 \mathrm{~b}$ & $0.12 \mathrm{e}$ & $17.4 \mathrm{~b}$ & $0.29 \mathrm{~b}$ \\
\hline Vd6 & $5.0 \mathrm{a}$ & $100.0 \mathrm{a}$ & $100.0 \mathrm{a}$ & $100.0 \mathrm{a}$ & $4.6 \mathrm{~b}$ & $0.10 \mathrm{e}$ & $18.6 \mathrm{~b}$ & $0.26 \mathrm{bc}$ \\
\hline $\mathrm{Vd} 8$ & $5.0 \mathrm{a}$ & $100.0 \mathrm{a}$ & $100.0 \mathrm{a}$ & $100.0 \mathrm{a}$ & $4.2 \mathrm{~b}$ & $0.27 \mathrm{~d}$ & $15.3 \mathrm{c}$ & $0.25 \mathrm{bc}$ \\
\hline Mean \pm SE & $4.4 \pm 0.6$ & $100.0 \pm 0.0$ & $100.0 \pm 0.0$ & $100.0 \pm 0.0$ & $4.08 \pm 0.32$ & $0.26 \pm 0.07$ & $17.34 \pm 0.69$ & $0.26 \pm 0.01$ \\
\hline Minimum & 2.0 & 100.0 & 100.0 & 100.0 & 2.9 & 0.1 & 15.3 & 0.22 \\
\hline Maximum & 5.0 & 100.0 & 100.0 & 100.0 & 4.7 & 0.5 & 19.0 & 0.29 \\
\hline $\begin{array}{l}\text { Mean } \pm \text { SE } \\
\quad(\text { negative control) }\end{array}$ & $0.0 \pm 0.0^{\mathrm{s}}$ & $0.0 \pm 0.0^{\mathrm{s}}$ & $0.0 \pm 0.0^{\mathrm{s}}$ & $0.0 \pm 0.0^{\mathrm{s}}$ & $7.4 \pm 0.05 b$ & $2.6 \pm 0.03 \mathrm{a}$ & $24.7 \pm 0.2 \mathrm{a}$ & $0.75 \pm 0.08 \mathrm{a}$ \\
\hline
\end{tabular}

Table 5D. Data for growth of inoculated plants at $35^{\circ} \mathrm{C}$.

\begin{tabular}{|c|c|c|c|c|c|c|c|c|}
\hline \multirow[b]{2}{*}{ Isolate $^{z}$} & \multirow{2}{*}{$\begin{array}{c}\text { Symptom } \\
\text { severity score }\end{array}$} & \multicolumn{3}{|c|}{ Colonization of stem segments (\%) } & \multirow{2}{*}{$\begin{array}{c}\text { Root } \\
\text { fresh wt } / g^{w}\end{array}$} & \multirow{2}{*}{$\begin{array}{c}\text { Root } \\
\text { dry wt } / g^{v}\end{array}$} & \multirow{2}{*}{$\begin{array}{c}\text { Shoot } \\
\text { fresh wt/gu }\end{array}$} & \multirow{2}{*}{$\begin{array}{c}\text { Shoot } \\
\text { dry wt } / g^{t}\end{array}$} \\
\hline & & $1 \mathrm{~cm}$ & $3 \mathrm{~cm}$ & $5 \mathrm{~cm}$ & & & & \\
\hline$\overline{\mathrm{Vd} 1}$ & $6.0 \mathrm{a}$ & $100.0 \mathrm{a}$ & 0.0 & 0.0 & $2.7 \mathrm{~b}$ & $0.30 \mathrm{~b}$ & $11.1 \mathrm{~b}$ & $0.14 \mathrm{c}$ \\
\hline $\mathrm{Vd} 2$ & $6.0 \mathrm{a}$ & $100.0 \mathrm{a}$ & 0.0 & 0.0 & $1.9 \mathrm{c}$ & $0.23 \mathrm{c}$ & $12.7 \mathrm{~b}$ & $0.19 \mathrm{~b}$ \\
\hline Vd5 & $6.0 \mathrm{a}$ & $100.0 \mathrm{a}$ & 0.0 & 0.0 & $3.1 \mathrm{~b}$ & $0.06 \mathrm{e}$ & $11.6 \mathrm{~b}$ & $0.19 \mathrm{~b}$ \\
\hline Vd6 & $6.0 \mathrm{a}$ & $100.0 \mathrm{a}$ & 0.0 & 0.0 & $3.1 \mathrm{~b}$ & $0.10 \mathrm{e}$ & $12.4 \mathrm{~b}$ & $0.17 \mathrm{bc}$ \\
\hline $\mathrm{Vd} 8$ & $6.0 \mathrm{a}$ & $100.0 \mathrm{a}$ & 0.0 & 0.0 & $2.1 \mathrm{~b}$ & $0.18 \mathrm{~d}$ & $10.2 \mathrm{c}$ & $0.16 \mathrm{bc}$ \\
\hline Mean \pm SE & $6.0 \pm 0.0$ & $100.0 \pm 0.0$ & $0.0 \pm 0.0$ & $0.0 \pm 0.0$ & $2.58 \pm 0.25$ & $0.24 \pm 0.03$ & $11.6 \pm 0.03$ & $0.17 \pm 0.03$ \\
\hline Minimum & 6.0 & 100.0 & 0.0 & 0.0 & 1.9 & 0.2 & 10.2 & 0.14 \\
\hline Maximum & 6.0 & 100.0 & 0.0 & 0.0 & 3.1 & 0.3 & 12.7 & 0.19 \\
\hline $\begin{array}{l}\text { Mean } \pm \text { SE } \\
\quad(\text { negative control) }\end{array}$ & $0.0 \pm 0.0^{\mathrm{s}}$ & $0.0 \pm 0.0^{\mathrm{s}}$ & $0.0 \pm 0.0^{\mathrm{s}}$ & $0.0 \pm 0.0^{\mathrm{s}}$ & $6.4 \pm 0.01 \mathrm{~b}$ & $1.8 \pm 0.08 \mathrm{a}$ & $21.1 \pm 0.2 \mathrm{a}$ & $0.54 \pm 0.12 \mathrm{a}$ \\
\hline
\end{tabular}

Means with SE of the mean are presented.

${ }^{\mathrm{z}}$ Isolates from symptomatic pumpkin plants in commercial fields were selected arbitrarily for the test.

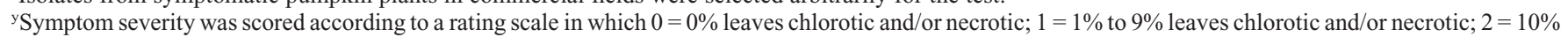

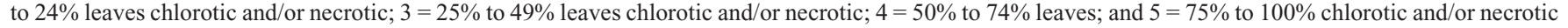
leaves.

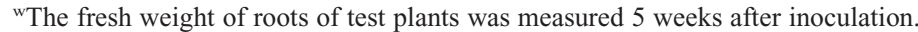

vThe dry weight to constant mass of roots of test plants was measured 5 weeks after inoculation.

uThe fresh weight of shoots of test plants was measured 5 weeks after inoculation.

${ }^{\text {t}}$ The dry weight to constant mass of shoots of test plants was measured 5 weeks after inoculation.

${ }^{\mathrm{s}}$ No disease was observed; data not included in analysis.

Numbers followed by the same letter in a column are not significantly different according to a LSD (HSD) test at $P \leq 0.05$. 
Table 6A. Analysis of variance of the effect of temperature on percentage of leaves symptomatic of infection.

\begin{tabular}{lrrrrrr}
\hline Source & df & \multicolumn{1}{c}{ Seq SS } & Adjusted SS & Adjusted MS & \multicolumn{1}{c}{ F } & \multicolumn{1}{c}{$P$} \\
\hline Isolate & 4 & 58.1 & 41.8 & 10.5 & 0.07 & 0.990 \\
Temperature & 1 & $16,847.5$ & $16,847.5$ & $16,847.5$ & 111.26 & $<0.001$ \\
Isolate*temperature & 4 & 46.5 & 46.5 & 11.6 & 0.08 & 0.988 \\
Error & 10 & 1514.3 & $1,514.3$ & 151.4 & & \\
Total & 19 & $18,466.3$ & & & & \\
\hline
\end{tabular}

Table 6B. Analysis of variance of the effect of temperature on time to maximum symptom severity.

\begin{tabular}{lrrccrr}
\hline Source & df & Seq SS & Adjusted SS & Adjusted MS & \multicolumn{1}{c}{ F } & \multicolumn{1}{c}{$P$} \\
\hline Isolate & 4 & 24.5 & 30.5 & 7.6 & 0.35 & 0.842 \\
Temperature & 1 & 812.3 & 812.3 & 812.3 & 36.77 & $<0.001$ \\
Isolate*temperature & 4 & 44.1 & 44.1 & 11.0 & 0.50 & 0.737 \\
Error & 10 & 220.9 & 220.9 & 22.1 & & \\
Total & 19 & 1101.8 & & & & \\
\hline
\end{tabular}

Seq $\mathrm{SS}=$ sequential sum of squares; $\mathrm{MS}=$ mean squares.

rate. Soesanto and Termorshuizen (2001) found that growth of six $V$. dahliae isolates was optimal at $25{ }^{\circ} \mathrm{C}$, but microsclerotia formation was highest at 20 or 15 to $20{ }^{\circ} \mathrm{C}$. Devaux and Sackston (1966) reported that although sparse growth of $V$. dahliae occurred at $30^{\circ} \mathrm{C}$, production of microsclerotia was inhibited. Iannou et al. (1977) and Jabnoun-Khiareddine et al. (2006) observed sparse, irregular growth at $30^{\circ} \mathrm{C}$.

There were no significant differences in symptom severity recorded for inoculated plants grown at $25 \pm 1$ and $30 \pm 1{ }^{\circ} \mathrm{C}$. At $20 \pm 1^{\circ} \mathrm{C}$, however, symptom scores dropped significantly compared with higher temperatures. Temperature-mediated changes in plant transpiration (Atkin and Tjoelker, 2003) may explain why symptom scores at $25 \pm 1$ and $30 \pm 1{ }^{\circ} \mathrm{C}$ appeared similar, although in vitro growth tests indicated that $30 \pm 1^{\circ} \mathrm{C}$ resulted in slower growth compared with $25 \pm 1{ }^{\circ} \mathrm{C}$. Generally, plant growth at $35 \pm 1{ }^{\circ} \mathrm{C}$ was not vigorous but the pathogen was still recovered from infected plants. Poor plant growth at suboptimal temperatures may mean that even a weakened pathogen can evoke maximum disease development (Agrios, 1997). The range of temperatures suitable for growth and production of microsclerotia in vitro was narrower than the range supporting infection of susceptible pumpkin plants by $V$. dahliae isolates. JabnounKhiareddine et al. (2006) also reported that higher temperatures $\left(21\right.$ to $\left.30^{\circ} \mathrm{C}\right)$ resulted in greater disease than lower temperatures (17 to $21{ }^{\circ} \mathrm{C}$ ) in greenhouse-maintained tomato plants. Conversely in cotton, verticillium wilt is milder under higher temperatures $\left(27.4{ }^{\circ} \mathrm{C}\right)$ and more severe when lower temperatures prevail $\left(25.7^{\circ} \mathrm{C}\right)$ under field conditions (Ma and Shezeng, 2000).

Disease can occur at any time of the year once a susceptible host is available; however, higher temperatures experienced during the dry season in Trinidad may contribute to increased disease severity. Surface temperatures in Trinidad lie between 20 and $35{ }^{\circ} \mathrm{C}$. Soil temperatures in the root zone (at a depth of $20 \mathrm{~cm}$ ) in open fields usually lie between 25 and $28{ }^{\circ} \mathrm{C}$ (data not shown). The surface and root zone temperatures are conducive to the growth and survival of the pathogen in the soil and will support infection in susceptible plants.

Deacon (2006) explained that, more often than not, fungi can tolerate a single suboptimal condition if all other growth requirements are met. It is difficult to predict the ability of a fungal pathogen to maintain its population under field conditions. Competitive interactions with other organisms and the response of the host plant to infection can also affect survival of the fungus. In this study, specific environmental factors that affect growth, production of microsclerotia, and severity of symptoms of $V$. dahliae infection in addition to those that have little impact on survival of the pathogen were identified. These findings were critical to informing disease management strategies.

\section{Literature Cited}

Agrios, G.N. 1997. Plant pathology. 4th Ed. Academic Press, London, UK, pp. 144-146.

Atkin, O.K. and M.J. Tjoelker. 2003. Thermal acclimation and the dynamic response of plant respiration to temperature. Trends Plant Sci. 8:343-351.

Broeckling, C.D., A.K. Broz, J. Bergelson, D.K. Manter, and J.M. Vivanco. 2008. Root exudates regulate soil fungal community composition and diversity. Appl. Environ. Microbiol. 74: 738-744.

Bruehl, G.W. 1987. Soilborne plant pathogens. Macmillan, New York, NY.

Chet, I. and Y. Hennis. 1975. Sclerotial morphogenesis in fungi. Annu. Rev. Phytopathol. 13:169-192.

Deacon, J.W. 2006. Fungal biology. 4th Ed. Blackwell Publishing, MA.

Devaux, A.L. and W.B. Sackston. 1966. Taxonomy of verticillium species causing wilt of horticultural crops in Quebec. Can. J. Bot. 44:803811.

Dutta, B.K. 1981. Effect of the chemical and physical condition of the soil on verticillium wilt of antirrhinum. Plant Soil 63:217-225.

Fayazalla, E.A., Y.M. Shabana, and N.S. Mahmoud. 2008. Effect of environmental conditions on wilting and root rot fungi pathogenic to Solanaceous plants. Plant Pathol. J. 7:27-33.

Garrett, S.D. 1970. Pathogenic root-infecting fungi. Cambridge University Press, London, UK.
Griffiths, D.A. 1970. The fine structure of developing microsclerotia of Verticillium dahliae Kleb. Arch. Microbiol. 74:207-212.

Hawksworth, D.L. and P.W. Talboys. 1970. Verticillium dahliae. CMI descriptions of pathogenic fungi and bacteria. No. 256. CABI Publishing, Wallingford, UK.

Iannou, N., W. Schneider, R.G. Grogan, and J.M. Duniway. 1977. Effect of water potential and temperature on growth, sporulation, and production of microsclerotia by Verticillium dahliae. Phytopathology 67:637-644.

Isaac, I. and C.Q. McGarvie. 1966. Dormancy and germination of resting structures of Verticillium spp. Trans. Br. Mycol. Soc. 49:669-678.

Jabnoun-Khiareddine, H., M. Daami-Remadi, K. Hibar, J. Robb, and M. El Mahjoub. 2006. Effect of temperature on verticillium wilts of tomato in Tunisia. Plant Pathol. J. 5:1-6.

Johnson, W.M., E.K. Johnson, and A. Brinkerhoff. 1980. Symptomology and formation of microsclerotia in weeds inoculated with Verticillium dahliae from cotton. Phytopathology 70:31-35.

Kabir, Z., R.G. Bhat, and K.V. Subbarao. 2004. Comparison of media for recovery of. Verticillium dahliae from soil. Plant Dis. 88:49-55.

Kim, Y.K., C.L. Xiao, and J.D. Rogers. 2005. Influence of culture media and environmental factors on mycelial growth and pycnidial production of Sphaeropsis pyriputrescens. Mycologia 97:25-32.

Koike, S.T., K.V. Subbarao, R.M. Davis, T.R. Gordon, and J.C. Hubbard. 1994. Verticillium wilt of cauliflower in California. Plant Dis. 78: 1116-1121.

Ma, P. and L. Shezeng. 2000. Incidence and damage of verticillium wilt of cotton in China, p. 353-357. In: Tjamos, E.C., R.C. Rowe, J.B. Heale and D.R. Fravel (eds.). Advances in verticillium research and disease management. APS Press, St. Paul, MN

Mol, L. 1995. Effect of plant roots on the germination of microsclerotia of Verticillium dahliae. II: Quantitative analysis of the luring effect of crops. Eur. J. Plant Pathol. 101:679-685.

Nadakavukaren, M.J. and C.E. Horner. 1959. An alcohol agar medium selective for determining verticillium microsclerotia in soil. Phytopathology 49:527-528.

Pegg, G.F. and B.L. Brady. 2002. Verticillium wilts. CABI Publishing, Wallingford, UK.

Rampersad, S.N. 2008. First report of Verticillium dahliae causing wilt in pumpkin in Trinidad. Plant Dis. 92:1136.

Rampersad, S.N. 2010. Verticillium dahliae (Kleb.) infecting pumpkin seed. J. Phytopathol. 158:329-333.

Robb, J. 2007. Verticillium tolerance: resistance, susceptibility or mutualism? Can. J. Bot. 85:903-910.

Sanogo, S. 2007. Interactive effects of two soilborne pathogens, Phytophthora capsici and Verticillium dahliae, on chile pepper. Phytopathology 97:37-43.

Schnathorst, W.C. 1965. Origin of new growth in dormant microsclerotial masses of Verticillium albo-atrum. Mycologia 57:343-351.

Schnathorst, W.C. 1981. Life cycle and epidemiology of verticillium, p. 81-111. In: Mace, M.A., A.A. Bell, and C.H. Beckman (eds.). Fungal wilt diseases of plants. Academic Press, New York, NY.

Schroth, M.N. and D.C. Hildebrand. 1964. Influence of root exudates on root-infecting fungi. Annu. Rev. Phytopathol. 2:101-132.

Smolińska, U. and B. Kowalska. 2008. The effect of organic amendments from Brassicaceae and Solanaceae plants and Trichoderma harzianum 
on the development of Verticillium dahliae Kleb. Veg. Crop. Res.Bull. 69:93-104.

Soesanto, L. and A.J. Termorshuizen. 2001. Effect of temperature on the formation of microsclerotia of Verticillium dahliae. J. Phytopathol. 149:685-691.

Subbarao, K.V., A. Chassot, R.R. Gordon, J.C. Hubbard, P. Bonello, R. Mullin, D. Okamoto, R.M. Davis, and S.T. Koike. 1995. Genetic relationships and cross pathogenicities of $\mathrm{Ver}$ ticillium dahliae isolates from cauliflower and other crops. Phytopathology 85:1105-1112.

Tjamos, E.C. and D.R. Fravel. 1995. Detrimental effects of sublethal heating and Talaromyces flavus on microsclerotia of Verticillium dahliae. Phytopathology 85:388-392.

Trinci, A.P.J. and K. Gull. 1970. Effect of actidione, griseofulvin and triphenyl tin acetate on the kinetics of fungal growth. J. Gen. Microbiol. 60:287-292.

Yamanaka, T. 2003. The effect off $\mathrm{pH}$ on the growth of saprotrophic and ectomycorrhizal ammonia fungi in vitro. Mycologia 95:584589.

Wilhelm, S. 1955. Longevity of the verticillium wilt fungus in the laboratory and field. Phytopathology 45:180-181. 